\title{
Terrestrial isopod diversity in the subtropical Neotropics: Itapuã State Park, southern Brazil
}

\author{
Maurício P. Almerãoํㅜ, Milton de S. Mendonça Jr. ${ }^{3}$, Aline F. Quadros ${ }^{1}$, Ezequiel Pedó², \\ Luiz G. R. Silva ${ }^{2} \&$ Paula Beatriz Araujo ${ }^{1}$
}

1. Programa de Pós-Graduação em Biologia Animal, Departamento de Zoologia, Instituto de Biociências, Universidade Federal do Rio Grande do Sul, Av. Bento Gonçalves 9500, prédio 43435, 91501-970 Porto Alegre, RS, Brasil. (pbaraujo@portoweb.com.br)

2. Departamento de Ecologia, Instituto de Biociências, Universidade Federal do Rio Grande do Sul.

3. Departamento de Zoologia e Genética, Universidade Federal de Pelotas, Campus Universitário, s/nº, Caixa Postal 354, 96010-900, Pelotas, RS, Brasil.

\begin{abstract}
We analysed species abundance and composition during one year of sampling at Itapuã State Park, a conservation unit in the State of Rio Grande do Sul, southern Brazil. Samples were collected monthly from May 2003 to April 2004 along a 4 km forest trail divided in three transects along the slopes of a small hill. Terrestrial isopods were hand searched by three people for 40 minutes at two sampling sites along each transect, summing 240 minutes of sampling effort per transect per month. Six species distributed in six families were found. The collector curve stabilised when half the samples were taken, demonstrating sampling sufficiency: analytical estimates did not predict more species to be found in the trail. Atlantoscia floridana (van Name, 1940) was dominant in all transects. Abundance varied along the year with a summer and a winter peak, but peaks were not consistent among transects. The first part of the trail, used for ecotourism, was less diverse, had less species ( 4 as compared to 6 in the other transects), and was thus also less similar in composition.
\end{abstract}

KEYWORDS. Diversity, terrestrial isopods, Oniscidea, Crustacea, soil fauna.

RESUMO. Diversidade de isópodos terrestres no neotrópico subtropical: Parque Estadual de Itapuã, sul do Brasil. Foi analisada a abundância e composição de espécies ao longo de um ano de amostragens no Parque Estadual de Itapuã, uma unidade de conservação no Estado do Rio Grande do Sul, no sul do Brasil. As amostragens foram feitas mensalmente de maio de 2003 a abril de 2004 , em uma trilha de $4 \mathrm{~km}$ na floresta, dividida em três transectos ao longo da encosta de uma pequena montanha. Os isópodos terrestres foram coletados manualmente por três pessoas por 40 minutos em dois locais em cada transecto, totalizando 240 minutos de esforço amostral por transecto, por mês. Foram encontradas seis espécies distribuídas em seis famílias. A curva do coletor estabilizou depois da metade das amostragens, demonstrando suficiência amostral: estimativas analíticas não predizem mais espécies na trilha. Atlantoscia floridana (van Name, 1940) foi a espécie dominante em todos os transectos. A abundância variou ao longo do ano com um pico no verão e no inverno, mas os picos não são consistentes entre os transectos. A primeira parte da trilha, usada para o ecoturismo, foi a menos diversa, apresentando menos espécies (4 comparadas às 6 nos outros transectos), e foi, portanto, menos similar na composição.

PALAVRAS-CHAVE. Diversidade, isópodos terrestres, Oniscidea, Crustacea, fauna de solo.

Terrestrial isopods are common representatives of soil meso- and macrofauna, where some species reach high densities: up to 1,040 individuals $\mathrm{m}^{-2}$ in the southern hemisphere (ARAUJO \& BOND-BUCKUP, 2005) and about 500 individuals $\mathrm{m}^{-2}$ in the northern hemisphere (HASSALL \& Dangerfield, 1990). A list of features making these organisms ideal for assessing soil sustainability is provided by PAOLETTI \& HASSALL (1999), which includes their importance on nutrient cycling and heavy metal accumulation (HoPKIN et al., 1986). Terrestrial isopods are soil-dwelling arthropods often showing sensitiveness to soil physical-chemical properties and limited dispersal capabilities, and thus may constitute good indicators of soil properties (PAOLETTI \& HASSALL, 1999), especially on a local scale perspective.

Recent studies on isopod assemblages were performed in Australia (JUDD \& HoRwITZ, 2003), Czech Republic (Tuf, 2003), Greece (LyMberakis et al., 2003; SFENTHOURAKIS et al., 2004; 2005), and Germany (ZIMMER, 2003). In southern Brazil, LOPES et al. (2005) studied isopod diversity at biogeographic scale on three different landscapes within an altitudinal gradient.

An inventory study was carried out in southern Brazil (Araujo et al., 1996), and brought to light the occurrence of two species in Itapuã State Park (ISP): Atlantoscia floridana (van Name, 1940), and Balloniscus sellowii (Brandt, 1833). Recently, Alboscia itapuensis Araujo \& Quadros, 2005 (ArAujo \& QuAdros, 2005) was described from the ISP area. These records correspond to $11 \%$ of the oniscidean fauna known for the State of Rio Grande do Sul (Araujo, 1999 a,b; Lopes et al., 2001; Lopes \& Araujo, 2003; Araujo \& Lopes, 2003; Araujo \& QuADROS, 2005).

The present study analyses isopod species richness, abundance, and species composition during one year of sampling at ISP.

\section{MATERIAL AND METHODS}

Study Area. This study was carried out at Itapuã State Park, a conservation unit with 5,566 ha, preserving part of the last remnants of natural ecosystems typical of the Porto Alegre region (Rio Grande do Sul's state capital). This area is characterised by a diversity of environments due to the overlap of two geotectonic provinces: the Coastal Province and the Sul-RioGrandense Shield (Menegat et al., 1998). According to Rio GRANDE Do Sul (1997), the landscape is composed of 
sandy beaches of the Patos lagoon and Guaíba Lake, dunes, and granitic hills. The vegetation cover is varied, ranging from grasslands to hill-slope forests with Atlantic forest influence; the climate is subtropical humid ( $\mathrm{Cfa}$ in the Köppen classification), with average annual rainfall of $1,300 \mathrm{~mm}$ and annual temperature averaging $17.5^{\circ} \mathrm{C}$.

Some areas suffered from intense human disturbance, which ranged from housing, especially in sites next to sandy beaches, to hunting in forested areas. A governmental intervention in 1990 regularised land use in the Park and closed it to tourism. This situation remained for ten years, during which time landscape regeneration was in progress until the recent reopening of the Park. The ISP currently receives hundreds of visitants per day, especially during summer weekends. There are trails used for ecotourism, which are visited by a limited number of people, accompanied by guides.

The trail $\left(30^{\circ} 34^{\prime} \mathrm{S}, 51^{\circ} 05^{\prime} \mathrm{W}\right)$ udes in this study is 4$\mathrm{km}$ long and 2-m wide, and was divided in three transects for the present study (Fig.1). Transect 1, and sometimes transect 2 , are used for ecotourism, whereas the remaining extension (transect 3 ) is almost always closed. In terms of physiognomy, transects are similar, with a well-defined tree layer, significant presence of lianas, and a limited occurrence of herbs. However, plant species composition varies, with some species found only in transect 1 (mainly shrubs and low trees, such as Erythroxylum argentinum Schultz, 1907 (Erythroxylaceae), Myrciaria cuspidata O. Berg, and Eugenia uruguayensis (Myrtaceae). Some species are only found in transect 2 (high trees, such as Ocotea indecora (Schott), Nectandra megapotamica (Sprengel) (Lauraceae), and Sorocea bonplandii (Baillon) (Moraceae)) and only two species belonged exclusively to transect 3 (Enterolobium contortisiliquum (Vellozo) (Fabaceae) and Syagrus romanzoffiana (Chamisso).

Sampling. Samples were collected monthly from May 2003 to April 2004. Terrestrial isopods were handsorted by three people for 40 minutes at two sampling sites (Fig. 1) along each transect, starting from transect 1 , summing up 240 minutes of sampling effort per transect per month. All specimens were fixed in ethanol at $70 \%$, identified and counted.

Statistical analyses. Statistical analyses were performed using the software EstimateS (COLWELL, 2005) in order to obtain sample accumulation curves and analytical estimates of species richness, as well as accumulated diversity indexes. Species richness, abundance, and assemblage equitability were statistically compared among transects and seasons using a 2-factor MANOVA (calculated with SPSS 10.0). Beta diversity (species

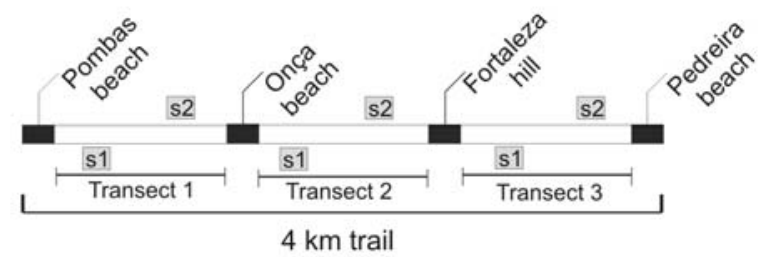

Fig. 1. Schematic sampling design for the three transects through forest in Itapuã State Park, southern Brazil. Open sections represent trails and dark sections are beaches and hilltops separating the transects; s1 and s2 represent sampling sites, one on each side of the trail. composition patterns) was also visually compared among transects and seasons by cluster analysis (Jaccard index, UPGMA method) and by statistical testing using two oneway ANOSIM tests with Bonferroni correction (calculated with PAST, HAMmER et al., 2001). Patterns of change in abundance relative to space (transects) and time (seasons) were compared for the two most abundant species.

\section{RESULTS}

Species composition. After $144 \mathrm{~h}$ of sampling and 6,541 individuals captured, six oniscidean species from six different families were found: A. floridana (Philosciidae), which has a Neotropical distribution; B. glaber Araujo \& Zardo, 1995 (Balloniscidae), which, to date, is recorded only from the State of Rio Grande do Sul (Bond-Buckup et al., 2003); Pseudodiploexochus tabularis (Barnard, 1932) (Armadillidae), a species from Africa; Novamundoniscus gracilis Lopes \& Araujo, 2003 (Dubioniscidae), a species recorded in southern Brazil (LoPES \& Araujo, 2003); Neotroponiscus daguerrii (Giambiagi de Calabrese, 1939) (Bathytropidae), often found associated with bromeliads (ARAujo et al. 1996) and Trichorhina sp. (Plathyarthridae). The latter is probably an undescribed species, and it is the same found by LOPES et al. (2005).

Alpha diversity. Sample-based species accumulation curve for field data show clear steps due to the small number of species found; the observed species curve stabilised after only half the samples were taken (data not shown), assuring sample sufficiency in terms of species present in the area. Analytical estimators of species richness do not predict more species in the area, and all curves stabilise at about six species.

On average, $181.69( \pm 15.65)$ individual isopods were collected per sample, with $2.69( \pm 0.15)$ species present. The MANOVA revealed no differences among seasons for the combined variables (species richness, abundance and assemblage equitability; Pillai's Trace, $\mathrm{F}_{9,72}=1.300$; $\mathrm{p}=0.252$ ), but differences among transects were significant in general (all three variables; Pillai's Trace, $\left.\mathrm{F}_{6.46}=2.739 ; \mathrm{p}=0.023\right)$. The tests for between-subjects effects showed richness to be significantly different among transects $\left(\mathrm{F}_{224}=4.481 ; \mathrm{p}=0.022\right)$, and abundance $(\log )$ was marginally significant $\left(\mathrm{F}_{2,24}=3.209 ; \mathrm{p}=0.058\right)$

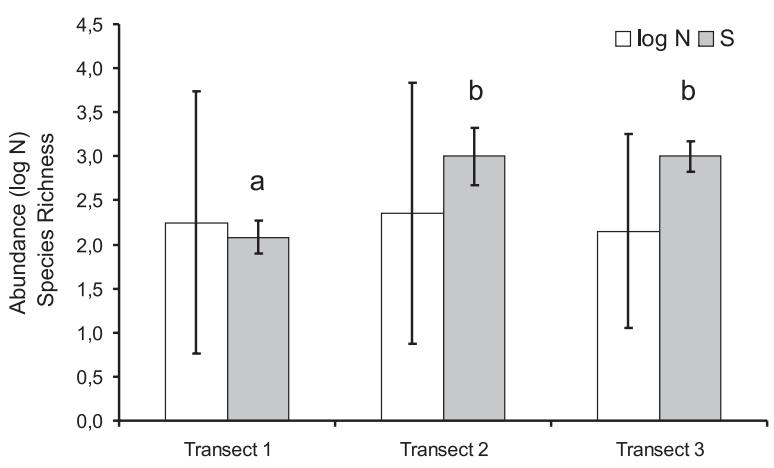

Fig. 2. Average abundance (log, white column) and species richness (grey column) between three transects across an anthropisation/ vegetation gradient in Itapuã State Park, southern Brazil. Bars are standard errors; columns with the same letter do not differ significantly for $\alpha=0.05$. 
(Fig. 2). No differences were found for equitability. Tukey post-hoc tests place transect $1(\bar{S}=2.08)$ as significantly poorer than 2 and 3 (both with $\bar{S}=3.00$ ).

Beta diversity. Figure 3 shows a species composition cluster for seasons and transects. This beta diversity pattern, analysed by ANOSIM tests for Jaccard and Morisita indexes (with monthly samples as repetitions, not shown in Fig. 3), did not show difference among seasons (Morisita: ranking within groups: 37.58; ranking among groups: $32.59 ; \mathrm{R}=-0.151 ; \mathrm{p}=0.872)$, but this pattern was different among trail transects (Morisita: ranking within groups: 22.61; ranking among groups: $37.58 ; \mathrm{R}=0.454 ; \mathrm{p}=0.002)$. Indeed, this difference is attributable to the fact that transect 1 lacked two species that appeared in the other transects (Neotroponiscus daguerrii and Novamundoniscus gracilis).

Atlantoscia floridana occurs in higher abundances first in transect 2, and then during winter in transect 1 , having its numbers reduced in spring (Fig. 4). These numbers increase again in summer, also concentrated in transect 2. Curiously, at the end of summer, abundances seem to shift again from transect 2 to transect 1 , as it was seen in the previous year. Abundance of B. glaber was consistently higher in transect 3 throughout the year, with peaks in winter and early summer. In summer, they seem to expand their distribution to transect 1 as well, but occurring in low numbers for the other seasons.

\section{DISCUSSION}

The recorded occurrence of B. glaber, P. tabularis, Novamundoniscus gracilis, Neotroponiscus daguerrii and of one unidentified species of Trichorhina is considered a significant contribution to the knowledge of terrestrial isopods ISP, which was previously limited to only three species. Due to this addition, the number of species found in ISP now corresponds to $29 \%$ of the known Oniscidea fauna of Rio Grande do Sul. This study also extended the area of occurrence of Novamundoniscus gracilis. This species was previously recorded in the sand bank vegetation of the Coastal Plains $\left(2^{\circ} 30^{\prime} \mathrm{S}\right.$, $49^{\circ} 78^{\prime} \mathrm{W}$ and $29^{\circ} 49^{\prime} \mathrm{S}, 50^{\circ} 04^{\prime} \mathrm{W}$ ), and in Brazilian Pine (Araucaria brasiliensis) Forest, in altitudes between 900 and 1,000 m, in the State of Rio Grande do Sul (LoPES \& ArAujo, 2003; Lopes et al., 2005).

The methods used here are different from other inventory works conducted in the same region, and thus direct comparisons of abundance, species richness, and composition are only tentative. Atlantoscia floridana was already described as a common, highly abundant species in another nearby conservation unit (ARAUJO \& BOND-BUCKUP, 2005), and as a dominant species in other regions with different physiographic characteristics (Brazilian coastal states, LEMOS DE CASTRO,1985; Atlantic Forest and Coastal Plains, Lopes et al., 2005). Thus, it seems this species is a successful generalist in terms of habitat, occurring in diverse environmental situations, and frequently in high numbers. LOPEs et al. (2005) provided the only other inventory dataset available for the region, in which the number of species per locality appears to be similar ( 2 to 3 species) to the values found in the present study. However, as mentioned above, the methods are different as to sampling effort.

The results found here indicate that the isopod

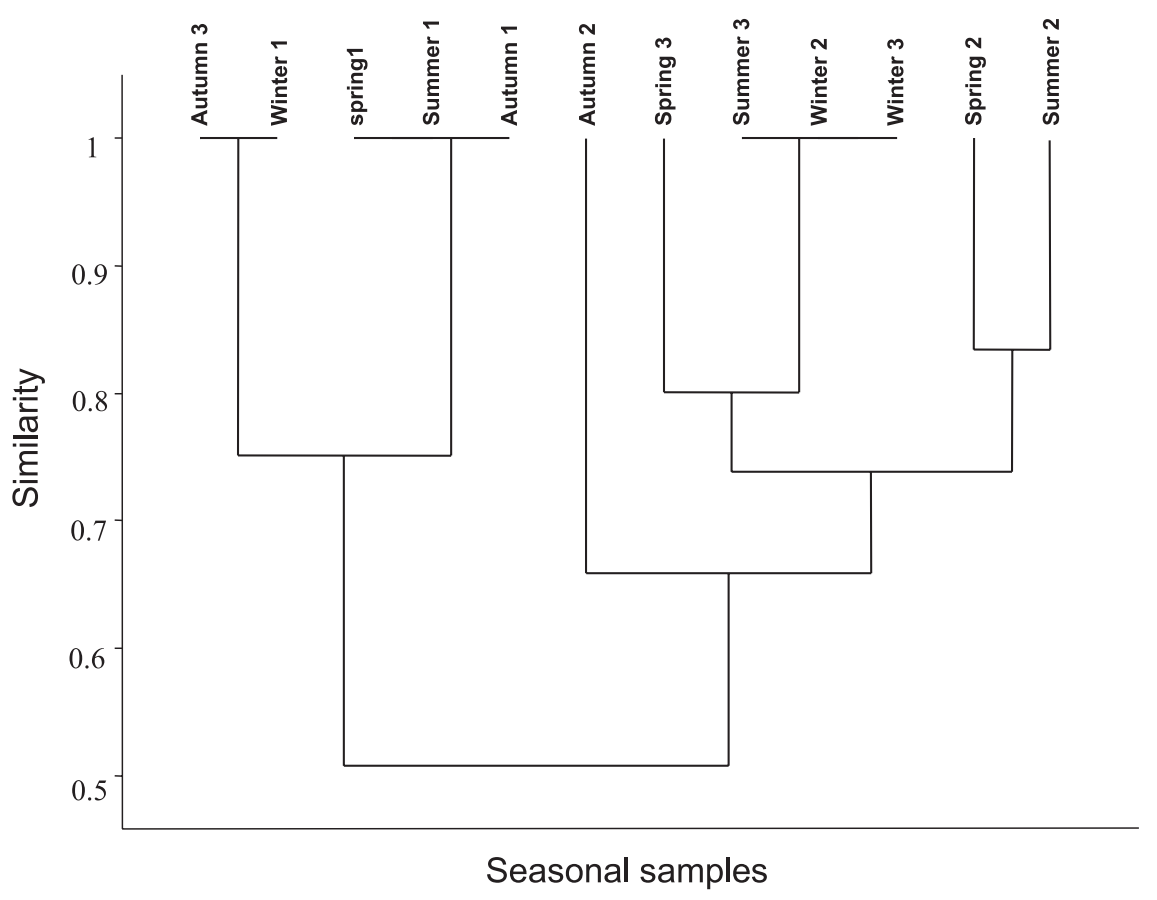

Fig. 3. Cluster analysis of similarity among seasons and trail transects in Itapuã State Park, southern Brazil. Similarity calculated with Jaccard (qualitative) index, groups joined by unpaired group method (UPGMA). Monthly samples were pooled for each season for clarity; these pooled seasonal samples are represented by the season name and transect number. 
a)

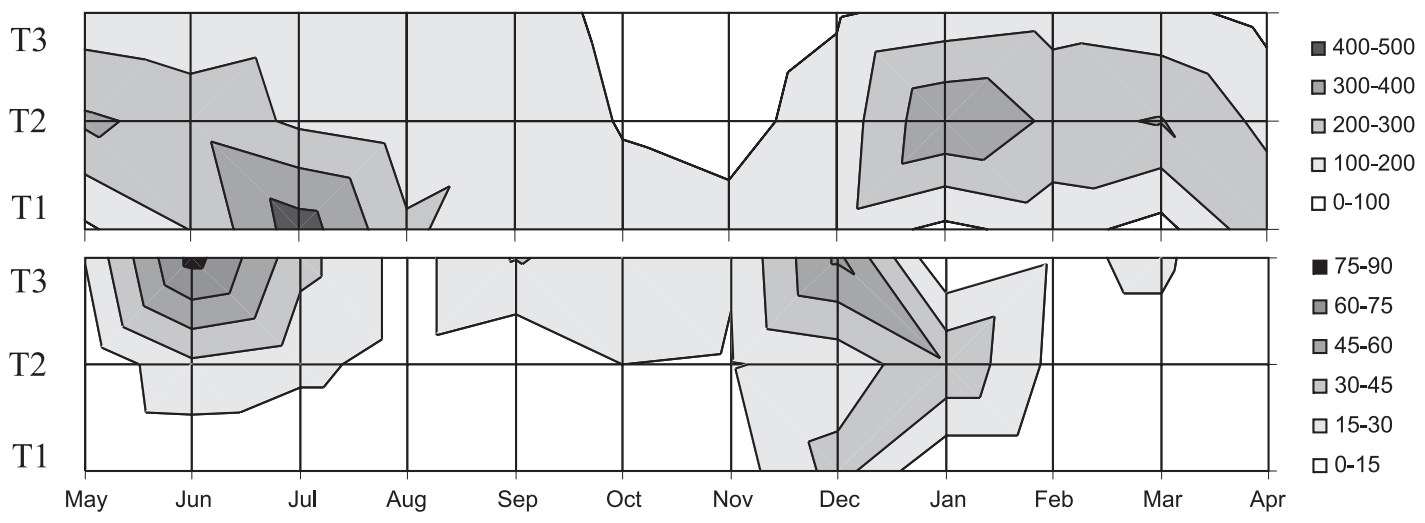

Fig. 4. Monthly abundance of two isopod species across the three transects (T1 to T3) of the sampled trail in Itapuã State Park, southern Brazil. Darker shades of grey indicate higher abundances. (a, Atlantoscia floridana; b, Balloniscus glaber).

assemblage differs among transects in terms of overall abundance, and more clearly for species richness, as well as for species composition. The sampled trail transects present many differences, such as vegetation composition and anthropic influence in the form of ecotourism visitation. These, in turn, affect other environmental aspects important for isopods, such as litter composition and soil structure (amount of organic matter and compaction). All of the above factors are known to influence isopod assemblages, and could be acting independently or in concert in the case of the Itapuã trail. Vegetation spatial heterogeneity can have a strong influence on the foraging behaviour of macrodecomposers (HASSALl et al., 2002). JABIN et al. (2004) demonstrated isopod density to be higher next to coarse woody debris. On the other hand, several studies showed that direct or indirect anthropic impacts on soil features have a clear influence on invertebrate species richness, abundance and/or composition, although there are still only a few reports involving Isopoda. SCHMIDT et al. (2005) studied the arthropod community of reed beds at cut and uncut sites, attributing the decreased abundance of isopods to a lower availability of litter in the cut reed. MoRETTI et al. (2004) observed that repeated fires negatively affected isopod species richness and abundance, and change species composition; Isopoda was the only taxonomic group in soil arthropod communities (out of 11) influenced by fire in all subjects analysed. DAUBER et al. (2005) demonstrated that isopod richness largely depends on human land use. In Brazil, PELlENS \& GARAY (1999) showed there were more isopods in the litter of coffee plantations than in native forests. More field data relating isopod diversity with vegetation and soil environmental aspects are needed to determine the precise influence of these factors on this important soil decomposer taxon.

Although our sampling involved a small spatial scale, the derived results show that soil fauna can respond at this scale to environmental changes. Whether these changes are responses to anthropic pressure (through trail visitation/ecotourism), plant cover, plant composition, or any combination of such factors remains to be determined. In particular, under conservation grounds, it may be argued that isopods, as small organisms important for soil function, could be good indicators to help decision-making in terms of zoning and management of conservation units.

Acknowledgements. The authors wish to thank the Secretaria Estadual do Meio Ambiente - SEMA, particularly Dr. Jan Karel Felix Mähler Jr., for granting permission to enter Parque Estadual de Itapuã (DEFAP Project 138) and supporting our research, as wells as Fundação de Amparo à Pesquisa do Estado do Rio Grande do Sul (FAPERGS, PROAPP, Proc. 0409925) for financial support. This is contribution number 472 of the Departamento de Zoologia, UFRGS.

\section{REFERENCES}

Araujo, P. B. 1999a. Subordem Oniscidea (isópodos terrestres, tatuzinhos). In: Buckup, L. \& Bond-Buckup, G. eds. Os crustáceos do Rio Grande do Sul. Porto Alegre, Editora da Universidade. p.237-256.

1999b. Two new species of Alboscia Schultz, 1995 from Rio Grande do Sul, Brazil (Isopoda, Oniscidea, Philosciidae). Crustaceana 72(5):487-496.

Araujo, P. B. \& Bond-Buckup, G. 2005. Population structure and reproductive biology of Atlantoscia floridana (van Name, 1940) (Crustacea, Isopoda, Oniscidea) in southern Brazil. Acta Oecologica 28(3):289-298.

Araujo, P. B. \& Lopes, E. R. C. 2003. Three new species of Benthana Budde-Lund (Isopoda: Philosciidae) from Brazil. Journal of Natural History 37(20):2425-2439.

Araujo, P. B. \& Quadros, A. F. 2005. A new species of Alboscia Schultz, 1995 (Crustacea: Isopoda: Oniscidea: Philosciidae) from Brazil. Zootaxa 1018:55-60.

Araujo, P. B.; Buckup, L. \& Bond-Buckup, G. 1996. Isópodos terrestres (Crustacea, Oniscidea) de Santa Catarina e Rio Grande do Sul, Brasil. Iheringia, Série Zoologia, (81):111-138.

Bond-Buckup, G.; Buckup, L. \& Araujo, P. B. 2003. Crustáceos. In: Fontana, C. S.; Bencke, G. A. \& Reis, R. E. eds. Livro Vermelho da Fauna Ameaçada de Extinção no Rio Grande do Sul. Porto Alegre, EDIPUCRS. 632p.

Colwell, R. K. 2005. EstimateS: Statistical estimation of species richness and shared species from samples. Version 7.5. Available at: <http://www.purl.oclc.org/estimates>. Access on: 20.04.2005.

Dauber, J.; Purtauf, T.; Allspach, A.; Frisch, J.; Voigtländer, K. \& Wolters, W. 2005. Local vs. landscape controls on diversity: a test using surface-dwelling soil macroinvertebrates of differing mobility. Global Ecology and Biogeography 14:213-221.

Hammer, Ø.; Harper, D. A. T. \& Ryan, P. D. 2001. PAST: Paleontological Statistics Software Package for Education 
and Data Analysis. Palaeontologia Electronica 4. Available at: <http://palaeo-electronica.org/2001_1/past/ issue1_01.htm>. Access on: 04.04.2005.

Hassall, $\bar{M}$ \& Dangerfield, J. M. 1990. Density-dependent process in the population dynamics of Armadillidium vulgare (Isopoda: Oniscidae). Journal of Animal Ecology 59:941-958.

Hassall, M.; Tuck, J. M.; Smith, D. W.; Gilroy, J. J. \& Addinson, R. K. 2002. Effects of spatial heterogeneity on feeding behaviour of Porcellio scaber (Isopoda: Oniscidea). European Journal of Soil Biology 28:53-57.

Hopkin, S. P.; Hardisty, G. \& Martin, M. H. 1986. The woodlouse Porcellio scaber as a biological indicator of zinc, cadmium, lead and cooper pollution. Environmental Pollution 11:271290.

Jabin, M.; Mohr, D.; Kappes, H. \& Topp, W. 2004. Influence of deadwood on density of soil macro-arthropods in a managed oak-beech forest. Forest Ecology and Management 194:6169.

JudD, S. \& HoRwitz, P. 2003. Diversity and biogeography of terrestrial isopods (Isopoda, Oniscidea) from southwestern Australia: organic matter and habitat utilization in seasonally dry landscapes. In: Sfenthourakis, S.; Araujo, P. B. DE; Hornung, E.; Schmalfuss, H.; Taiti, S. \& Szlávecz, K. eds. The Biology of Terrestrial Isopods V. Leiden, Brill. p.191-216. (Crustaceana Monographs 2).

Lemos de Castro, A. 1985. Considerações sobre Atlantoscia alceui Ferrara \& Taiti, 1981 (Isopoda, Oniscoidea, Philosciidae). Revista Brasileira de Biologia 45(4):417442 .

Lopes, E. R. C. \& Araujo, P. B. 2003. Nova espécie de Novamundoniscus Schultz (Isopoda, Oniscidea, Dubioniscidae) para o Rio Grande do Sul, Brasil. Revista Brasileira de Zoologia 20(4):611-614.

Lopes, E. R. C.; Araujo, P. B. \& Bond-Buckup, G. 2001. Pseudodiploexochus tabularis (Barnard), novo registro de Armadillidae (Crustacea, Isopoda, Oniscidae) para o Brasil. Revista Brasileira de Zoologia 18(2):655-656.

Lopes, E. R. C.; MendonçA, M. S., JR.; Bond-Buckup, G. \& Araujo, P. B. 2005. Oniscidea diversity across three environments in an altitudinal gradient in northeastern Rio Grande do Sul, Brazil. European Journal of Soil Biology 41(3-4):99-107.

Lymberakis, P.; Mylona, M. \& Sfenthourakis, S. 2003. Altitudinal variation of oniscidean communities on Cretan mountains.
In: Sfenthourakis, S; Araujo, P. B.; Hornung, E.; Schmalfuss, H.; TAiti, S. \& Szlávecz, K. eds. The biology of terrestrial isopods V. Leiden, Brill. p.217-230. (Crustaceana Monographs 2).

Menegat, R.; Porto, M. L.; Carraro, C. C. \& Fernandes, L. A. D. 1998. Atlas ambiental de Porto Alegre. Porto Alegre, Editora da Universidade. 150p.

Moretti, M.; Obrist, M. K. \& Duelli, P. 2004. Arthropod biodiversity after forest fires: winners and losers in the winter fire regime of the Southern Alps. Ecography 27:173-186.

Paoletti, M. G. \& Hassall, M. 1999. Woodlice (Isopoda: Oniscidea): their potential for assessing sustainability and use as bioindicators. Agriculture, Ecosystems and Environment 74:157-165.

Pellens, R. \& Garay, I. 1999. A comunidade de macroartrópodos edáficos em uma plantação de Coffea robusta Linden (Rubiaceae) em uma floresta primária em Linhares, Espírito Santo, Brasil. Revista Brasileira de Zoologia 16(1):245-258.

Schmidt, M. H.; Lefevbre, G.; Poulin, B. \& Tscharntke, T. 2005. Reed cutting affects arthropod communities, potentially reducing food for passerine birds. Biological Conservation 121:157-166.

RIO GRANDE DO SUL. 1997. Plano de Manejo Parque Estadual de Itapuã. Porto Alegre, Departamento de Recursos Naturais Renováveis. 158p.

Sfenthourakis, S.; Anastasiou, I. \& Strutenschi, T. 2005. Altitudinal terrestrial isopod diversity. European Journal of Soil Biology 41:91-98.

Sfenthourakis, S.; Giokas, S. \& Tzanatos, E. 2004. From sampling stations to archipelagos: investigating aspects of the assemblage of insular biota 2004. Global Ecology and Biogeography 13(1):23-35.

Tuf, I. H. 2003. Development of the community structure of terrestrial isopods (Isopoda, Oniscidea) after a summer flood. In: Sfenthourakis, S.; Araujo, P. B.; Hornung, E.; Schmalfuss, H.; Taiti, S. \& Szlávecz, K. eds. The biology of terrestrial isopods V. Leiden, Brill. p.231-242. (Crustaceana Monographs 2).

Zimmer, M. 2003. Habitat and resource use by terrestrial isopods (Isopoda: Oniscidea). In: Sfenthourakis, S.; Araujo, P. B.; Hornung, E.; Schmalfuss, H.; Taiti, S. \& Szlávecz, K. eds. The biology of terrestrial isopods V. Leiden, Brill. p.243-261. (Crustaceana Monographs 2).

Recebido em outubro de 2005. Aceito em agosto de 2006. ISSN 0073-4721

Artigo disponível em: www.scielo.br/isz 